\section{Cow's milk, infant formula and iron-deficiency anemia}

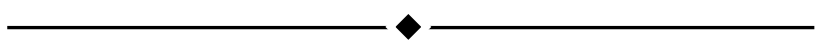

Dear Editor,

With reference to the review published in Jornal de Pediatria linking cow's milk and iron deficiency anemia, ${ }^{1}$ we do not believe that the article maintained due differentiation between whole cow's milk and infant formula, including its role in the prevention of iron deficiency anemia.

The review, ${ }^{1}$ based on citation number 20 (by Hadler, Colugnati and Sigulem) stated that "Modified milk, enriched with iron, however, reduces the chances of anemia by increasing the density of iron in the milk." ${ }^{1}$ It should be pointed out that the same study also demonstrated that infant formula, when used as the primary complement to or substitute for breastmilk, reduced the risk of anemia by 5.1 times, compared with introducing cow's milk on weaning. Another Brazilian study ${ }^{2}$ confirmed this finding (odds ratio $=1.9$ ). Thus, initial introduction of infant formula, rather than whole cow's milk, is associated with a lower probability of developing anemia.

When dealing with blood loss from the digestive tract "caused by exposure to cow's milk", the authors state that this does not cause clinical repercussions. ${ }^{1}$ This statement was based on references 57,58 and 60 , which also allow for other interpretations. Iron nutritional status was adequate in the infants enrolled in those studies. It is therefore possible that even in the cases of infants losing blood in feces, the observation period may not have been long enough for "clinical repercussions" to occur. At this point, it should be remembered that it is only in the more severe forms of iron deficiency anemia that clinical repercussions can be identified by physical examination. ${ }^{3}$ The authors of one of these three studies sum up their findings with the statement that, "blood loss is present in 91 /2-month-old infants but is of such low intensity that its clinical significance seems questionable. Nevertheless, infants without cow milk-induced blood loss were in better iron nutritional status than infants who showed blood loss." They also state that although the level of blood lost is relatively low, cow's milk consumption is undesirable before 12 months (infant formula should be preferred), as recommended by the American Academy of Pediatrics. They also comment that the method employed for measuring blood in feces could have suffered interference from porphyrinic derivatives from meat in the diet of the infants studied, which could have caused problems with interpretation of the results. In order to avoid this problem a Brazilian study 4 employed specific immunochromatographic methods to test for human hemoglobin in the feces of infants aged 10 to 12 months. The prevalence of anemia (72.4\%) was extremely high. They found that $46.9 \%$ of the 64 infants who were fed on whole cow's milk tested positive for occult blood in feces and had median serum ferritin levels statistically lower than the infants who tested negative for blood in feces. They concluded that fecal blood loss was an aggravating factor for iron deficiency. ${ }^{4}$ This result is in agreement with earlier published studies showing that fecal blood loss associated with whole cow's milk consumption can have negative repercussions for iron nutritional status in infants.

In its conclusion, the review article states 1 "stimulation of the practice of exclusive maternal breastfeeding up to 6 months and its continuation until at least 24 months, together with a complementary diet rich in iron and elements that facilitate its absorption, in common with the fortification of infant feeds with iron, are measures of great importance for the prevention of anemia and of its consequences during childhood.". No bibliographic reference, however, is offered to confirm the efficacy and efficiency of such feeding practices.

For infants who are breastfed up to 24 months, individual medical iron supplementation is the only way to prevention iron deficiency. The World Health Organization itself recognizes that individual iron supplementation should be adopted to prevent infant iron deficiency. Prophylactic iron should be given once a day ( $2 \mathrm{mg} / \mathrm{kg}$ dose) and employed from 6 to 24 months.

In contrast, there is no evidence to show that non-milk complementary foods are capable of meeting the iron requirements of infants. A study undertaken on the outskirts of São Paulo city shows that the iron density of homemade complementary foods prepared for infants is very low even when beef is one of the ingredients. ${ }^{5}$ Furthermore, theoretical exercises to develop menus that meet the iron requirements of iron have not produced results compatible with the quantity of food usually consumed at this age, due to the small gastric capacity proper to the age group.

Over recent decades the duration of natural breastfeeding in Brazil has risen, however, unfortunately, a significant proportion of infants is still subjected to early weaning, including during the first six months of life. Such infants are not covered by the measures for iron deficiency prevention laid out in the review article in question. ${ }^{1}$ These children are, therefore, being doubly penalized: first because they are not breastfed for long enough, and, second, because they are in a high risk group for iron deficiency without being the targets of any alternative prevention proposal.

These weaned infants would benefit from individual supplementation as referred to above. Indeed, since 1995 the Brazilian Society of Pediatrics (Sociedade Brasileira de Pediatria) itself has recommended supplementation with iron 
from the fourth or sixth month of life onwards, irrespective of the type of milk the infant is given.

An additional alternative for these weaned infants is the use of iron fortified infant formula. Classic studies in Europe and Chile show that the iron nutritional status of infants at the end of the first year of life is better among those given formula or milk fortified with iron than among infants previously fed with human milk or with unfortified cow's milk or formula. The World Health Organization recognizes that the use of cow's milk or formula fortified with iron sulphate is an adequate alternative, as well as considering other fortification options, such as flour, corn and rice, that have been tried out in some countries, but which may have satisfactory impacts among older age groups and not for infants.

Finally, it should be emphasized that iron deficiency, in its pre-anemic phases (depletion of iron store), may cause intellectual deficits, perhaps irreversibly, indicating that iron supplementation or the employment of infant formula fortified with iron should be prioritized while more suitable preventative measures are identified.

It should also be remembered that the prevalence of iron deficiency anemia among infants has been rising since the seventies, ${ }^{6}$ and is currently the principal nutritional deficiency in public health. The decision to publish a review ${ }^{1}$ of a theme of such relevance demonstrates the efforts that Jornal de Pediatria has been making to improve and bring up to date the knowledge of Pediatricians, who are central figures to fight against iron deficiency anemia in infants. In the same vein we hope that our comments also contribute to the same end.

\section{References}

1. Oliveira MAA, Osorio MM. Consumo de leite de vaca e anemia ferropriva na infância. J Pediatr (Rio J). 2005;81:361-7.

2. Neves MBP, Silva EMK, Morais MB. Prevalência e fatores associados à deficiência de ferro em lactentes atendidos em um centro de saúde-escola em Belém, Pará, Brasil. Cad Saude Publica. 2005;21:1911-8.

3. Morais MB, Sdepanian VL. Sinais clínicos de anemia no diagnóstico de anemia: uma ação tardia e ineficiente no combate à deficiência de ferro. Rev Saude Publica. 2004;38:329-30.

4. Fernandes S, Morais MB, Amancio OMS. Perda de sangue oculto nas fezes como fator agravante da deficiência de ferro em lactentes. Anais do Congresso Brasileiro de Gastroenterologia Pediátrica; 2004; Salvador.

5. Ribeiro P, Sigulem DM, Morais TB. Determinação laboratorial de macronutrientes, ferro e sódio em diferentes tipos de refeições de sal preparadas no domicílio, destinadas a crianças menores de 18 meses - resultados preliminares [Resumo]. Rev Paul Pediatr. 2004;22:49.

6. Sigulem DM, Tudisco ES, Goldenberg P, Athaide MM, Vaisman E. Anemia ferropriva em crianças do município de São Paulo. Rev Saude Publica. 1978;12:168-78.

doi:10.2223/JPED.1467

\section{Mauro Batista de Morais}

Professor adjunto, Livre-docente da Disciplina de Gastroenterologia Pediátrica, Universidade Federal de São Paulo - Escola Paulista de Medicina (UNIFESP-EPM), São Paulo, SP, Brasil. Coordenador, Programa de Pós-Graduação em Pediatria e Ciências Aplicadas à Pediatria, UNIFESP-EPM, São Paulo, SP, Brasil.

E-mail: mbmorais@osite.com.br

\section{Dirce Maria Sigulem}

Coordenadora, Programa de Pós-Graduação em Saúde MaternoInfantil, Universidade de Santo Amaro (UNISA), Santo Amaro, SP, Brasil. Professora titular, Faculdade da Medicina, UNISA, Santo Amaro, SP, Brasil.

E-mail: dmsigulem@uol.com.br

\section{Authors' reply}

Dear Editor,

We would like to comment on the principal criticisms raised in the letter by the readers Mauro Batista de Morais and Dirce Maria Sigulem on the subject of our article, "Cow's milk consumption and iron deficiency anemia in children", published in this periodical.

At no point in our article did we contradict the concept that infant formula enriched with iron and used as a complement to or substitute for breastmilk is associated with a lower probability of developing iron deficiency anemia. Indeed, in the section on the bioavailability of iron in cow's milk we cited three references on the subject. ${ }^{1-3}$ In our final considerations we recommend the fortification of food for children with iron. Here, it is taken as read that infant formula is included. However, it should be remembered that in the Brazilian population a large proportion of children are anemic (for example: prevalence of anemia of $40.9 \%$ in children under 5 years and of $67.3 \%$ in those under 1 year, in Pernambuco state) ${ }^{4}$ and are surviving in very poor socioeconomic conditions, meaning that infant formula is very hard to acquire and, as a result, it would not have been appropriate for us to indicate it as viable for the prevention of iron deficiency anemia in our infant population.

We recognize the difficulties involved in meeting the iron requirements of children less than 2 years of age through complementary feeding. 5,6 However, it is the encouragement of exclusive breastfeeding up to 6 months and of continued breastfeeding up to 24 months, together with a complementary diet rich in both iron and in components that facilitate its absorption that is recommended by international organizations that concern themselves with health and infant nutrition. ${ }^{5}$ In Brazil, the Health Ministry has made the fortification of wheat flour and corn flour with iron as part of the actions being taken for the prevention and control of anemia (Resolution RDC no 344 - published - 13/12/02) and has created the National Iron Supplementation Program (Decree no 730 - published$13 / 05 / 05)$. The latter program is being implemented in certain towns, with ferrous sulphate distribution at a weekly dose of $25 \mathrm{mg}$ of elemental iron for children from 6 to 18 months. ${ }^{7}$

We would also like to emphasize the need for health professionals, particularly those who work in primary care, to pay more attention to nutrition and the factors that predispose to anemia, so that they can thereby adequately carry out 
activities for prevention, healthcare and nutritional support of children.

Considering that the Jornal de Pediatria is a periodical of great importance, not just for keeping pediatricians informed, but for all professionals involved in children's healthcare, we are grateful for the contribution made by the readers named above and also for the opportunity given us by this esteemed journal to widen discussion of our work.

\section{References}

1. De Angelis RC, Ctenas MLB. Biodisponibilidade de ferro na alimentação infantil. Temas de Pediatria. 1993;52.

2. Ziegler EE, Fomon SJ. Strategies for the prevention of iron deficiency: iron infant formulas and baby foods. Nutr Rev. 1996; 54:348-54

3. Cowin AE, Emond A, Emmett P. Association between composition of the diet and hemoglobin and ferritin levels in 18-month-old children. Eur J Clin Nutr. 2001;55:278-86.

4. Osório MM, Lira PIC, Batista-Filho M, Ashworth A. Prevalence of anemia in children 6-59 months old in the state of Pernambuco, Brazil. Rev Panam Salud Publica. 2001;10:101-7.

5. World Health Organization. Complementary feeding of young children in developing countries. A review of current scientific knowledge. Geneva: WHO/NUT; 1998.

6. Giugliani ER, Victora CG. Alimentação complementar. J Pediatr (Rio J). 2000;76(Suppl 3):S253-62.

7. Brasil, Ministério da Saúde. Manual operacional do Programa Nacional de Suplementação de Ferro. http://dtr2004. saude.gov.br/nutricao/documentos/manual_ferro.pdf. Access: 14/03/06.

doi:10.2223/JPED.1468

\section{Maria A. A. Oliveira}

Doutora, Universidade Federal de Pernambuco (UFPE), Recife, PE, Brasil. Professora adjunta, Departamento de Nutrição, Universidade Federal de Alagoas (UFAL), Maceió, AL, Brasil.

\section{Mônica M. Osório}

Doutora, Universidade Federal de Pernambuco (UFPE), Recife, PE, Brasil. Professora adjunta, Departamento de Nutrição, UFPE, Recife, PE, Brasil.

\section{Rhinovirus and bronchiolitis}

\section{Dear Editor:}

It was with great satisfaction that I read "Rhinovirus and acute bronchiolitis in young infants" by Pitrez et al. ${ }^{1}$ The article deals with a relevant subject, emphasizing the need for more and better investigation of childhood viral respiratory diseases, given the discovery of new viruses and the possibly increased importance of others, as the article states. These etiologic investigations have an increased degree of importance because respiratory infections are the most common cause of hospitalization during the first year of life. ${ }^{2}$ Furthermore, there are also reports of new viruses, like the metapneumovirus, being related with bronchiolitis. ${ }^{3}$

I would like to make some observations about the results reported: the first is related to the fact that they did not find any cases of the parainfluenza virus in their sample. Data from the Santa Casa de São Paulo and the Faculdade de Medicina de Jundiaí demonstrate that $30 \%$ of samples collected from 400 children in 2005 were positive for respiratory viruses. Respiratory syncytial virus (RSV) was the first, and the type 3 parainfluenza virus the second most frequent etiologic agent of viral respiratory infection. Similar findings were reported by data from an investigation at the acute respiratory infection surveillance program run by the São Paulo Health Department. ${ }^{4,5}$

Another important observation is on the occurrence of RV as etiologic agent of bronchiolitis. We can observe in Table 2 of the article that RSV was identified in 33 of the 35 samples and RV in six. Just two cases, therefore, did not present RSV. The article does not make clear which viruses were isolated in the two cases where RSV was absent.

In their discussion, the authors observed that there was not sufficient evidence from their results to be able to state that RV was an etiologic agent of bronchiolitis, which is a correct statement, since RV always, or almost always, appeared together with RSV. It is not clear whether or not RV was an aggravating factor or if it affected prognosis.

In my opinion, RV was just an accidental finding. The opinion of the study authors on this subject is of importance to the direction of future research into respiratory viruses in our country.

\section{References}

1. Pitrez PM, Stein R, Stuermer L, Macedo IS, Schmitt VM, Jones $\mathrm{MH}$, et al. Bronquiolite aguda por rinovírus em lactentes jovens. J Pediatr (Rio J). 2005;81:417-20.

2. Shann F, Woolcock A, Black R, Cripps A, Foy H, Harris M, et al. Acute respiratory tract infections: the forgoten pandemic. Clin Infect Dis. $1999 ; 28: 189-91$.

3. Williams JV. The clinical presentation and outcomes of children infected with newly identified respiratory tract viruses. Infect Dis Clin N Am. 2005;19:569-84.

4. Souza MC, Matsumoto TK, Lima LR, Requejo $H$, Durigon $E$, Pechini R, et al. Preliminary molecular analysis of respiratory syncytial virus. In: São Paulo Abstracts of XVI National Meeting of Virology; 2005 Nov 22-25; Salvador, Brasil. [abstract 404]. Virus Rev Res. 2005;10(1 Suppl):S193.

5. Silva Ramos S. Vigilância da influenza no município de São Paulo - 2005. www.grog.saude.sp.gov.br. Access: 12/12/2005

doi:10.2223/JPED.1469

\section{Eitan Naaman Berezin}

Professor adjunto, Faculdade de Ciências Médicas, Santa Casa de São Paulo, São Paulo, SP, Brasil. Chefe, Setor de Infectologia Pediátrica, Santa Casa de São Paulo, São Paulo, SP, Brasil.

E-mail: berezin@terra.com.br 